\title{
光刺激に床答する分子集合体の構築とその応用 \\ Developments and Applications of \\ Photoresponsive Molecular Assemblies
}

\section{赤松 允顕}

東京理科大学理工学部先端化学科

\section{T 278-8510}

千葉県野田市山崎 2641

\section{Masaaki AKAMATSU}

Department of Pure and Applied

Chemistry, Faculty of Science and

Technology, Tokyo University of Science

2641 Yamazaki, Noda, Chiba

278-8510, Japan
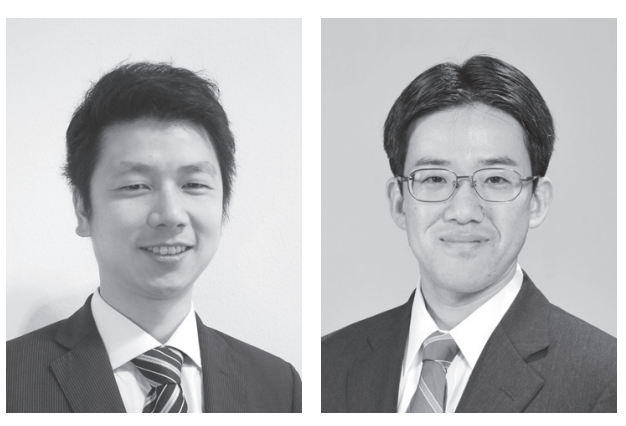

酒井 健一

東京理科大学理工学部先端化学科

干 278-8510

千葉県野田市山崎 2641

Kenichi SAKAI

Department of Pure and Applied

Chemistry, Faculty of Science and

Technology, Tokyo University of Science

2641 Yamazaki, Noda, Chiba

278-8510, Japan

\section{酒井 秀樹}

東京理科大学理工学部先端化学科

\section{干 278-8510}

千葉県野田市山崎 2641

\section{Hideki SAKAI}

Department of Pure and Applied Chemistry, Faculty of Science and Technology, Tokyo University of Science 2641 Yamazaki, Noda, Chiba 278-8510, Japan

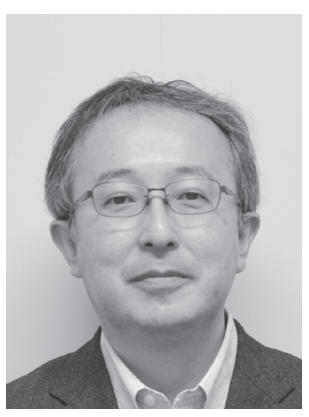

論文要旨：界面活性剤が形成する分子集合体の構造を光刺激により変化させれば, 内包した物質の放出制 御が可能となり, 薬物や有効成分の送達システムが構築できる。本総説では, これまでに筆者らが開発した 光応答性界面活性剤について紹介する。アゾベンゼン修飾カチオン性界面活性剤は, 紫外光および可視光照 射にともなうtrans-cis 異性化により臨界ミセル濃度が大きく変化した。桂皮酸修飾光分解性界面活性剂は, 紫外光照射にともない界面物性が変化し, さらに紐状ミセル構造の変化に由来した水溶液粘度や微粒子分散 性の光制御に成功した。オンデマンドな界面物性制御を可能にするため, 光応答性界面活性剂の光応答スピー ドの高速化を検討した。紫外光照射にともないロフィンダイマーから生成するロフィルラジカルの再結合反 応は，ミセル内部の閉鎖空間内で高速化することが分かった。両親媒性ロフィンダイマーを用いることで, その水溶液の表面張力を紫外光照射により数スケールで制御することができた。in situ 小角中性子散乱 (SANS) を用いた解析の結果, 両親媒性ロフィンダイマーは楕円体ミセルを形成し, 紫外光照射 ON-OFF にともない伸張・収縮を高速で繰り返すことが分かった。さらに, このミセル水溶液を用いることで, 可溶 化されたモデル薬物を光照射により高速で放出制御できた。 
Abstract: Photo-induced morphological changes in the molecular assemblies formed by surfactants enable controlled release of incorporated substances, which can be applied in delivery systems of drugs, active components. In this article, we review the photoresponsive surfactants, which have been reported by our group. An azobenzene-based cationic surfactant represented changes in critical micelle concentration, accompanied by trans-cis photoisomerization with ultraviolet or visible light irradiation. A cinnamic acid-based photocleavable surfactant showed photoinduced changes in the interfacial properties, and also represented controlled solution viscosity and dispersibility of the nanoparticles. To realize on-demand control of the interfacial properties, the response speed by photoirradiation need to be fast. Recombination of lophyl radicals, produced from amphiphilic lophine dimers (3TEG-LPD) by ultraviolet light irradiation was enhanced in the confined space of the micelles. Surface tension of an aqueous solution of 3TEG-LPD decreased in several seconds upon ultraviolet light irradiation. in situ small-angle neutron scattering (SANS) system revealed 3TEG-LPD form elliptical micelles and the long axis was readily elongated by ultraviolet light irradiation. When the light irradiation was stopped, the morphology of the micelle readily recovered to the initial form. Solubilization capacity of the amphiphilic lophine dimer for a model drug was readily controlled by photoir radiation.

Key words: surfactant, interfacial property, self-assembly, photo, small-angle neutron scattering (SANS)

\section{1 はじめに}

生物は外部刺激に応答する様々な機能を持っている。 例えば，我々が物体の形や色を認識できるのは，眼球の 桿体細胞中に存在するレチナールが光刺激にともない異 性化し，この情報が視神経を通り脳で視覚情報として認 識されるためである。また, ある環境条件（温度, 光, 湿度など）がそろった時に植物種子が発芽する現象も, 生物の持つ優れた刺激応答性分子機構の一例として挙げ ることができる。このように，分子やその集合体に刺激 応答性を付与できれば, 目的とする物性や機能を任意の タイミングで発現させることが可能となる。

界面活性剂 (両親媒性分子) の構造中に外部刺激にと もない構造変化する置換基を導入すると, 形成する分子 集合体の構造制御が可能となる。これにより, 例えば, 分子集合体内部に取り込んだ有効成分（薬物，香料，栄 養成分など）を，目的とするタイミングで外部刺激によ り放出することが可能となる（Fig. 1a）。また，刺激応 答性界面活性剤は分子集合体として機能するだけでな く, 特定の界面に吸着することで, 外部刺激による界面 物性の制御（表面・界面張力, 濡れ性, 分散性など）が 可能となる。これまでに, 外部刺激として光・電気・磁 場・ $\mathrm{pH}$ ・ 温度の変化が用いられてきた ${ }^{1)}$ 。中でも光刺 激はクリーンかつ空間分解能や波長選択性に優れるた め, 光刺激に応答し機能変化する分子集合体に注目が集 まっている ${ }^{1-4)}$ 。

界面活性剂構造中に導入する光応答性部位として, 光 照射にともない可逆的な構造変化を起こし, 色調をはじ めとする光 · 電子物性が変化する光異性化分子がよく用 いられる。例えば，アゾベンゼン（trans 体-cis 体）， ス (a)

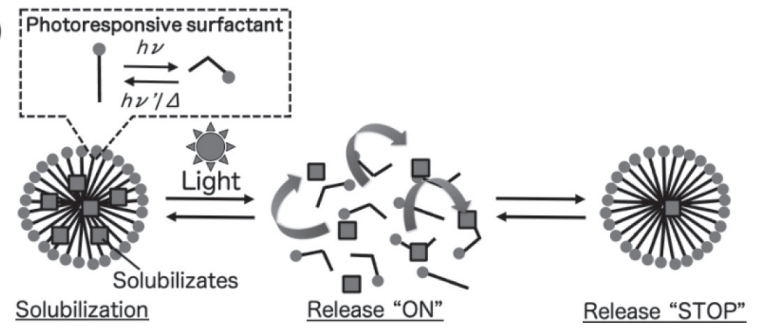

(b)



Fig. 1 (a) Controlled release of solubilizates with the micelles formed by photoresponsive surfactants (b) Photochromism of azobenzene, diarylethene and spiropyrane as typical photochromic compounds.

チルベン（trans 体-cis 体，二量体），ジアリールエテン (開環体一閉環体), スピロピラン（スピロピラン型ーメ ロシアニン型）の光異性化反応が挙げられる（Fig. 1b)。例えば, Shinkaiらは光応答性部位としてアゾベ ンゼン部位を持つ界面活性剤を設計し，光照射にともな い形成するミセル構造が変化することを報告している ${ }^{5)}$ 。 Hatton らはアゾベンゼン修飾非イオン性界面活性剤の 親水基や踈水基のバランス (鎖長) が，光照射にともな う水溶液の表面張力変化の挙動に大きく影響することを 見出した ${ }^{6)}$ 。Raghavan, Zakin らは, アゾベンゼンある いは桂皮酸誘導体／界面活性剂混合系で形成される紐状 ミセルの構造変化を利用し, 溶液の熱伝導性を光照射に 
より制御し，効率的な熱交換システムへの応用を見出し た ${ }^{7,8)}$ 。このように, 界面活性剤が持つ界面活性能や分 子集合能に加えて, 様々な特徵を持つ光応答性分子を組 み合わせることで，目的とする機能を持った光応答性界 面活性剂・分子集合体を開発できる。

本稿では，これまでに筆者らが開発した（1）アゾべ ンゼン修飾，（2）桂皮酸修飾，そして（3）ロフィンダ イマー修飾光応答性界面活性剂について紹介する。特に, オンデマンドな界面物性の制御を目指し，光照射にとも なう機能変化の高速化やそのダイナミクスに着目した最 近の試みについて紹介したい。

\section{2 アゾベンゼン修飾界面活性剤の分子集合体形成と光 可溶化制御}

光応答性界面活性剂として, Fig. 2 に示すアゾベンゼ ン部位を有するカチオン性界面活性剤（4-butylazobenzene-4'-(oxyethyl) trimethylammonium bromide : AZTMA）を用いた。AZTMA は水溶液中で紫外光あるい は可視光の照射にともないtrans-cis 異性化反応を示す。 また, 電気伝導度測定より求めた臨界ミセル濃度 $(\mathrm{cmc})$ は, trans 体で $2.7 \mathrm{mM}$, cis 体で $8.2 \mathrm{mM}$ であり光異性

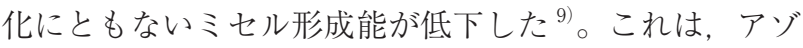
ベンゼン部位の光異性化にともなう嵩高さや極性の変化 に起因すると考えられる。さらに, AZTMAのミセル 水溶液にモデル香料であるエチルベンゼンを可溶化させ たところ，その可溶化量を光照射により制御できること が分かった ${ }^{9)}$ 。これより，紫外光および可視光の照射に ともないミセル形成能を制御できることが示唆された。 そこで, AZTMAの光異性化がミセル構造およびその 可溶化能に及ぼす影響を調べるために，小角中性子散乱 (SANS) による解析を行った。SANS 法では, 得られ る散乱プロファイルに対して，分子集合体の形や大きさ 等を仮定した理論曲線のカーブフィッティング（モデル 解析）を行うことで，詳細な分子集合体構造を解析する ことができる。

$5 \mathrm{mM}$ AZTMA 重水溶液のSANS 測定結果を Fig. 2 に示す ${ }^{10)}$ 。この散乱プロファイルをモデル解析した結果, ミセル形状は楕円体であり，その長半径は約 $39 \AA$ ，短 半径は約 $21 \AA$ と算出された。次に, 溶液に紫外光を照 射し trans 体から cis 体への光異性化を進行させると, 散乱強度がほぼバックグラウンドのレベルまで低下し, ミセルの崩壊が確認できた。続いて, 可視光照射により trans 体へ異性化させるとプロファイルはほぼ初期の状 態まで回復した。以上より，AZTMA 溶液において， ミセルの崩壊・形成が光照射により可逆的に生じること を確認できた。

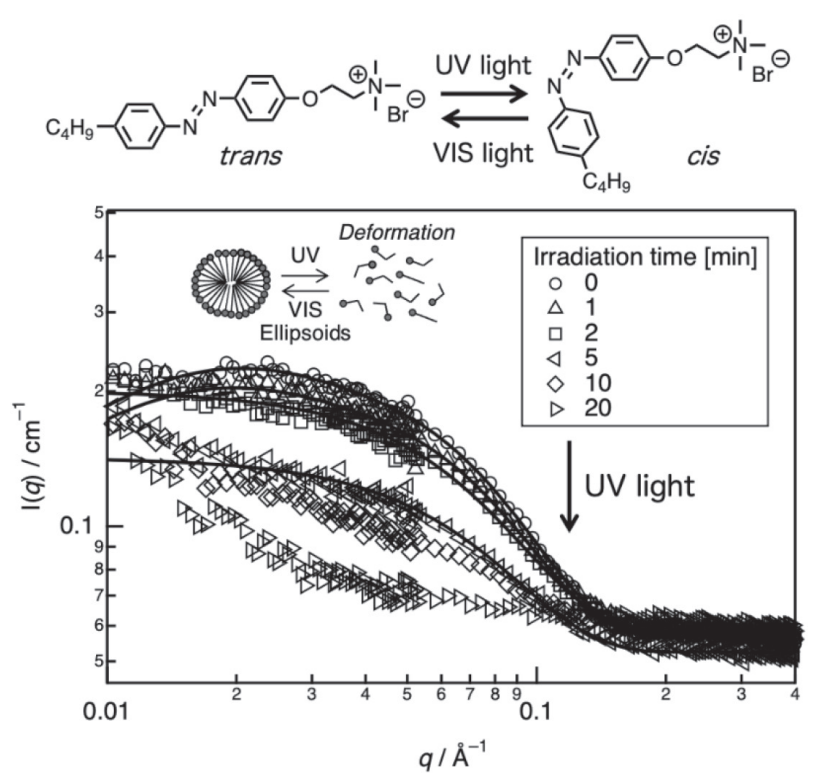

Fig. 2 Photochromism of AZTMA and variations in SANS profiles of $5 \mathrm{mM}$ AZTMA in $\mathrm{D}_{2} \mathrm{O}$.

次に, 被可溶化物質としてモデル香料であるエチルベ ンゼンを添加した AZTMA 重水溶液についても SANS 測定を行い, 可溶化系におけるミセル構造に及ぼす光照


溶化物質としてエチルベンゼンを可溶化限界量以上添加 し，光照射前後での SANS 測定およびその解析を行っ た。光照射前では, 得られたプロファイルは半径に分布 を持つ球体モデルによく一致し, 半径は 30〜 35 ^算 出された。これより, AZTMA ミセルはエチルベンゼ ンの可溶化にともない膨潤することが分かった。

続いて紫外光照射を行うと, 散乱プロファイルが変化 し，半径および体積分率が増大した。これより，紫外光 照射により cis-AZTMA が形成すると, エチルベンゼン の可溶化が促進され，ミセルをさらに膨潤させることが 分かった。さらに, 引き続き可視光を照射したが, 散乱 プロファイルに顕著な変化は見られなかった。ここで, 解析により得られた散乱体の半径と体積分率から, 単位 容積当たりのミセル数を算出した。すると, 紫外光照射 により，ミセル数は減少するにも関わらず，ミセル 1 個 当たりに可溶化されるエチルベンゼンの量は増大してい た。これは，紫外光照射により生成する cis 体ミセルが， trans 体ミセルよりもエチルベンゼンに対して親和性が 高いためだと考えられる。そのため, 光照射によりミセ ル数は減少するにも関わらず，全体としてAZTMA 溶 液の可溶化量は増大したと考えられる。実際に, 高速液 体クロマトグラフィー（HPLC）による可溶化量測定か ら, ミセル 1 つ当たりに可溶化されるエチルベンゼンの 分子数を算出したところ, 紫外光照射にともないおおよ 
そ200から 300 に増加することが分かった。本系では, 光照射にともないエチルベンゼンの可溶化量が増加する ため, 水中に溶存した油性物質の光回収などへの応用が 期待される。

以上より，アゾベンゼン修飾カチオン性界面活性剂 （AZTMA）のミセル水溶液を用い，光照射にともなう 油性物質の可溶化能制御に成功した。さらに，小角中性 子散乱 (SANS) 測定により, 光照射で誘起される分子 集合体の解析が可能となった。また，本稿では紹介でき なかったが, AZTMA を用いることで, 紐状ミセル ${ }^{11)}$ やベシクルの形成 ${ }^{12)}$ の光制御にも成功している。特に, 紐状ミセル系では水溶液の粘弾性を光により可逆的に制 御することが可能となり，可溶化／放出の制御のみなら ず，化粧品やUV インク等への応用も今後期待できる。

\section{3 桂皮酸修飾光開裂性界面活性剂による界面物性の光 制御}

界面活性剂は使用後の残存による人体や環境への悪影 響の懸念があり，それが払拭されればより安全に使用で きる。例えば，近年マイクロプラスチックが社会問題と なり, 生分解性プラスチックに注目が集まっている。そ こで筆者らは, 光照射にともない開裂し, 環境負荷の低

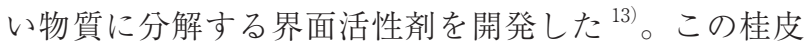
酸修飾光開裂性界面活性剂（C4-C-N-PEG9）は，紫外光 照射にともない, 香料として用いられるクマリン誘導体 および保湿成分であるエチレングリコールを生成物とし て生じる（Fig. 3）。ここでは，C4-C-N-PEG9 を用いた 界面物性の光制御ならびに紐状ミセルの構造变化を利用 した光による水溶液の粘弾性制御について紹介する。

各水溶液濃度の C4-C-N-PEG9 水溶液に対して静的表 面張力測定を行うと, 優れた表面張力低下能を示し, そ の $\mathrm{cmc}$ は $0.21 \mathrm{mM}$ であることが分かった。また，スク アラン /C4-C-N-PEG9 水溶液系における界面張力測定 を行った。C4-C-N-PEG9 無添加の場合，スクアラン／ 水系の界面張力は $44.3 \mathrm{mN} / \mathrm{m}$ であったが，水相への C4-C-N-PEG9 の添加にともない最大で約 $5 \mathrm{mN} / \mathrm{m}$ まで 低下した ${ }^{13)}$ (Fig. 3)。また，C4-C-N-PEG9 水溶液に紫外 光を照射すると, 界面張力の值が増大した。これは, 光 開裂反応の進行にともない界面安定化に寄与する水溶液 中の C4-C-N-PEG9 濃度が低下したためだと考えられ る。以上より, 新規光開裂性界面活性剂 (C4-C-N-PEG9) を用い，その光開裂反応にともなう界面物性の制御に成 功した。

次に，C4-C-N-PEG9 を用いた光による水溶液の粘弾 性制御を行った。紐状ミセル水溶液は, ミセルが高分子 様に成長し互いに絡み合うことで特異な粘弾性挙動を示
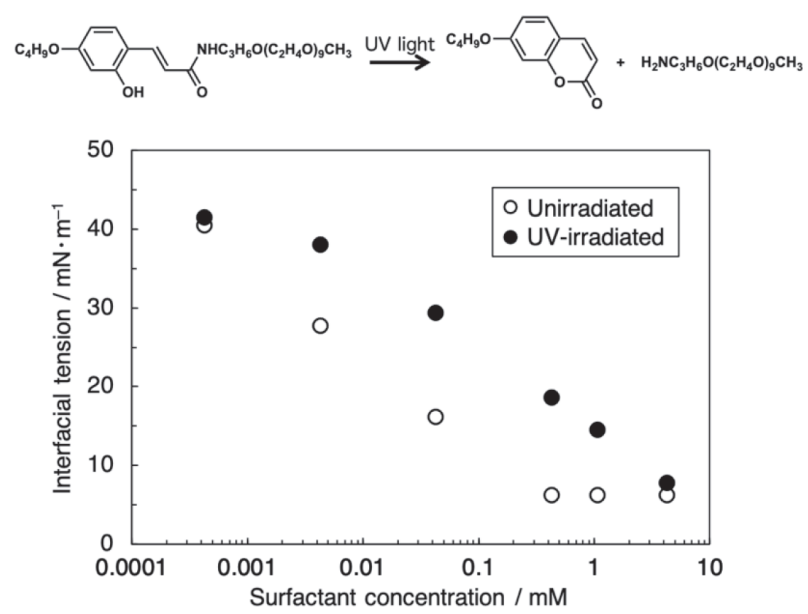

Fig. 3 Photo-cleavage of C4-C-N-PEG9 and interfacial tension of a squalane/water interface measured at various C4-C-N-PEG9 concentrations.

す。紐状ミセルを形成することが知られているフイトス テロールエトキシレート (PhyEO20)／ドデシルエトキ シレート (C12EO4) 水溶液に C4-C-N-PEG9 混合すると, 水溶液のゼロシアー粘度が $10 \mathrm{~Pa} \cdot \mathrm{s}$ から $0.001 \mathrm{~Pa} \cdot \mathrm{s}$ へ と大きく低下し，ニュートン流体類似の挙動が観測され た ${ }^{14)}$ 。この水溶液に紫外光を照射すると, 粘度が $2 \mathrm{~Pa} \cdot \mathrm{s}$ へ大きく増大し, shear-thinning 挙動を示す非ニュート ン流体へと変化した。以上の結果から, C4-C-N-PEG9 が PhyEO20/C12EO4 混合系における紐状ミセルの形成 を阻害し, 光照射にともなう C4-C-N-PEG9 の光分解反 応によって紐状ミセルが再形成したと考えられる。以上 のように, 新規光開裂性界面活性剤を用い, 界面物性や 水溶液粘度の光制御に成功した。さらに, C4-C-N-PEG9 と類似の構造を持つアニオン性光開裂性界面活性剂 $\left(\mathrm{C}_{8}-\right.$ C-Gly）を用いることで，水溶液中において光照射にと もなう固体微粒子（シリカ微粒子）の分散性制御にも成 功した ${ }^{15)}$ 。

\section{4 界面を反応場に利用したロフィンダイマーの光異性 化反応の高速化}

ここまで紹介してきた筆者らの研究例も含め, これま でに光応答性界面活性剤について数多く展開されてき た ${ }^{1,2}$ 2,4)。しかし，これまでの報告例では，界面物性や 分子集合体の構造変化に分〜時間オーダーの光照射を必 要とし, 任意のタイミングで目的とする機能を発現させ ることは難しい。この点を克服できれば，例えば目的と する時間に必要とする量の薬物を患部に放出でき, 効率 的かつ的確なオンデマンドな薬剤送達システムが実現で きる。上記の目的を達成するためには, 分子集合体の構 造を高速で制御する必要がある。そこで, 筆者らはロフィ ンダイマーと呼ばれるフォトクロミック分子に着目し 


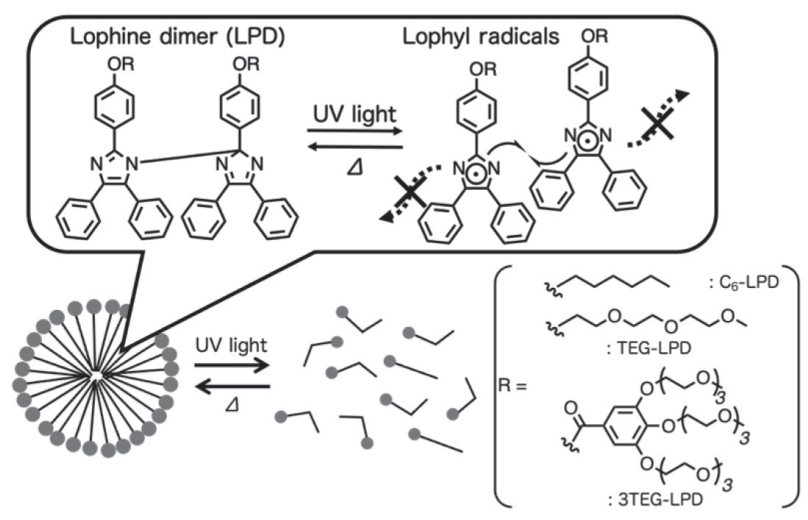

Fig. 4 Photochromism of lophine dimer (LPD) and the LPD derivatives.

た。ロフィンダイマーは紫外光照射にともない一対のロ フィルラジカルに解離し, この活性なラジカルは熱的に 再結合する（Fig. 4）。しかし， ロフィルラジカルは溶液 中を自由拡散するため, この再結合反応は極めて遅い。 Abe らはこのロフィルラジカルの拡散を抑制するため, ロフィン骨格同士を化学的に架橋することで, 再結合反 応がミリからフェムト秒スケールまで高速化することを 報告している ${ }^{16)}$ 。この知見を基にして, 筆者らは過去に, ミセル内部の閉じた凝集空間をロフィルラジカルの拡散 抑制に用い，再結合反応の速度向上を図った（Fig. 4）。

カチオン性界面活性剤である Cetyltrimethylammonium Bromide（CTAB）のミセル水溶液中にアルキル化 したロフィンダイマー誘導体 $\left(\mathrm{C}_{6}-\mathrm{LPD}\right)$ を可溶化させ ると, ラジカル種が自由に拡散可能な有機溶媒中に比べ て, ロフィルラジカルの再結合速度が 100 倍以上も促進 された ${ }^{17)}$ (Fig. 5)。続いて, ミセル内部へのロフィンダ イマー誘導体の可溶化能を上げ，生成するロフィルラジ カルの衝突頻度の増大を試みた。この目的のため, 非イ オン性親水基である Triethyleneglycol（TEG）基を導 入したロフィンダイマー誘導体（TEG-LPD）を同様に $\mathrm{CTAB}$ ミセル中に可溶化させたところ, 再結合速度が さらに促進した ${ }^{18)}$ 。

この結果を基に，ミセル内部でのロフィンダイマーの 濃度をさらに増加させ, 生成するロフィルラジカルの拡 散距離を縮めるために，ロフィンダイマーのみから形成 されるミセルの構築を試みた ${ }^{18,19)}$ 。この目的のため, TEG 基を複数導入した両親媒性ロフィンダイマー （3TEG-LPD）を新たに設計・合成した（Fig. 4）。合成 した 3TEG-LPD 水溶液の表面張力測定から, $\mathrm{cmc}$ は 0.80 $\mu \mathrm{M}$, 最低到達表面張力 $\gamma_{\mathrm{cmc}}$ は $46.5 \mathrm{mN} / \mathrm{m}$ と決定された。 また, 動的光散乱測定より, TEG-LPD は直径約 $7.4 \mathrm{~nm}$ のミセルを形成することが示唆された。同様に，3TEGLPD ミセル水溶液において, 紫外光照射により生成す

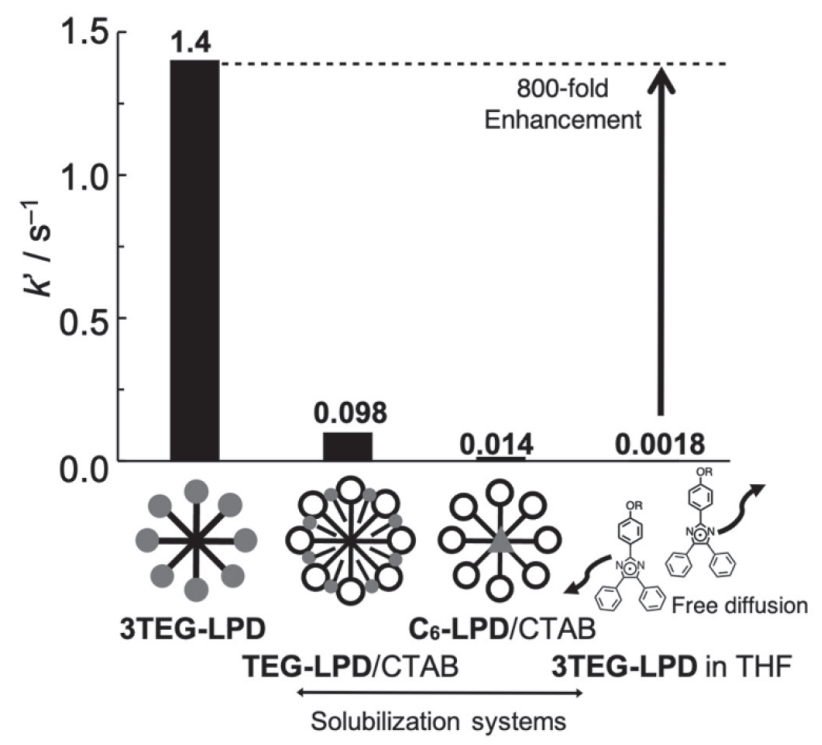

Fig. 5 Apparent reaction rates of the recombination $\left(k^{\prime} / \mathrm{s}^{-1}\right)$ of the aqueous solutions of $0.5 \mathrm{mM}$ 3TEG-LPD, 0.5 $\mathrm{mM}$ TEG-LPD/50 $\mathrm{mM}$ CTAB and saturated $\mathrm{C}_{6^{-}}$ LPD/50 mM CTAB, and THF solution of TEG-LPD.

るロフィルラジカルの再結合反応は, 有機溶媒中に比べ て 800 倍程度も促進した（Fig. 5）。

以上の結果より，ミセル内部の凝集空間を利用するこ とで, 光照射により生成するロフィラジカルの再結合反 応が著しく促進された（Fig. 5)。また, その再結合速度 はミセル内部におけるロフィンダイマー濃度に依存する ことが分かった。これは, 活性なラジカル種間の距離が 衝突頻度に影響することを示している。これより, ロフィ ンダイマーの光異性化反応を高速化する上で, 分子集合 体内部の凝集空間は適当な反応場だと言える。

次に, 3TEG-LPDの高速光異性化能を利用した界面 物性の高速光制御に取り組んだ。 $5 \mathrm{mM}$ 3TEG-LPD 水 溶液に対して紫外光照射を行うと, 表面張力值が秒オー ダーで低下した。続いて, 光照射を止めると, 同様に秒 オーダーでほぼ元の值まで回復した。これより, 光照射 にともない生成するロフィルラジカルは, 気/水界面上 で密にパッキングし界面をより安定化すると考えられ る。また, 気/水界面の Gibbs 膜中や分子集合体中にお いて, このラジカル種が近接しているため, 速やかに再 結合反応が進行したと考えられる。以上より, 分子集合 体内部の凝集空間を活用し, ロフィルラジカルの再結合 反応の促進と, 表面張力の高速光制御が可能となった。

\section{5 両親媒性ロフィンダイマーを用いたミセル構造の高 速光制御}

両親媒性ロフィンダイマーが形成するミセル構造の解 析と光照射にともなうその時間変化を追跡した。この目 
(a)

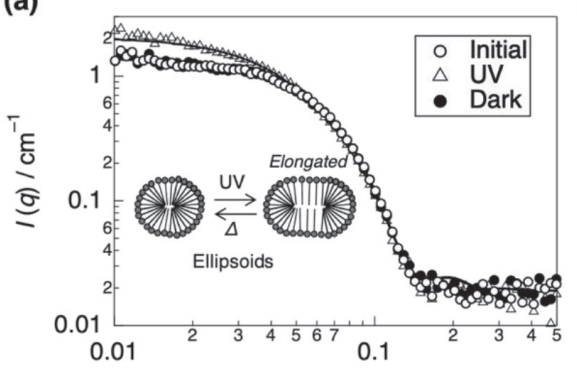

(c)

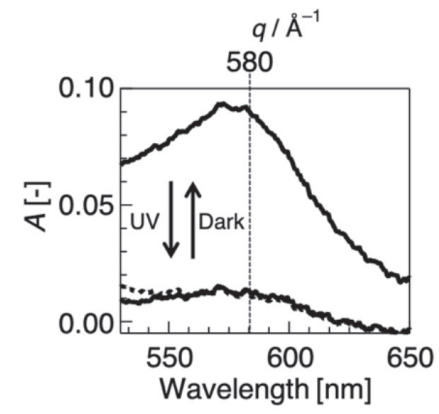

(b)
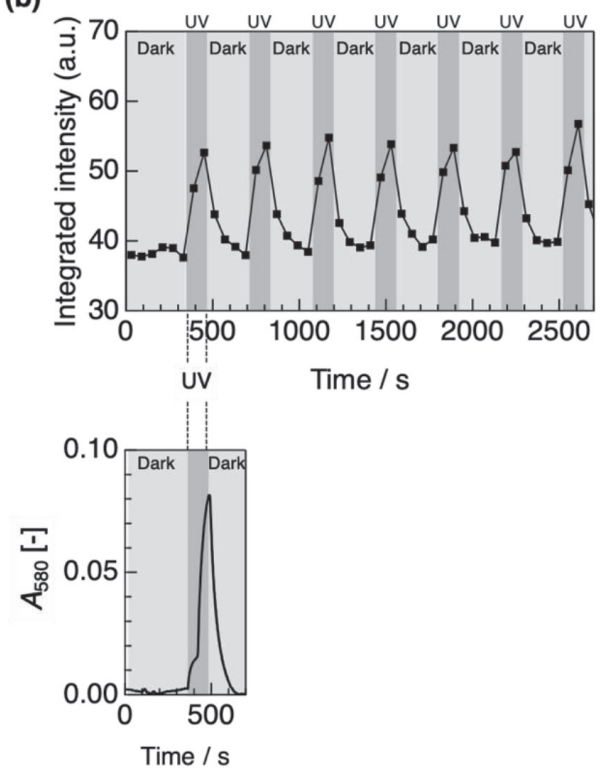

Fig. 6 Results of simultaneous measurements of in-situ SANS and UV/Vis absorption spectra. (a) SANS profiles of $10 \mathrm{mM}$ 3TEG-LPD in $\mathrm{D}_{2} \mathrm{O}$ before and after 2 min UV irradiation and 4 min standing in the dark with curve fitting. (b) The integrated scattering intensity of the SANS profiles of 3TEG-LPD in the $q$-region of $0.01-0.05 \AA^{-1}$ during cycles of irradiation and standing in the dark. (c) UV/Vis absorption spectra before and after UV irradiation and standing in the dark (left), and the temporal changes in absorption at $580 \mathrm{~nm}$ during the cycle using an in-situ UV/Vis absorption spectrometer (right).

的を果たすためには, SANS 装置に光照射ランプと紫外・ 可視吸収分光光度計をドッキングさせた新たなin situ 計測システムが有用である ${ }^{20-23)}$ 。そこで, 我々は一般 財団法人総合科学研究機構 (CROSS) の岩瀬裕希博士 と共同で茨城県東海村にある J-PARC（Japan Proton Accelerator Research Complex）研究施設の大型中性子 源に設置されたSANS 装置（BL-15，大観）に本装置系 を構築した ${ }^{24)}$ 。これにより，光照射にともなう光異性化 反応が進行した後，ミセル構造変化がどのような時間ス ケールで起きるかを詳細に調べることが可能となる ${ }^{25,26) 。}$

Fig. 6aに, $10 \mathrm{mM}$ 3TEG-LPD 重水溶液の SANS プロ ファイルを示す。モデル解析の結果, 得られたプロファ イルは楕円体モデルによくフィットし, 長半径は約 47 $\AA$ ，短半径は約 $28 \AA$ であった。このミセル溶液に紫外 光を照射すると, 直ちに長半径が約 $70 \AA$ に変化した。 一方, 短半径に変化はなかった。次に, 紫外光照射を止 めると, プロファイルは直ちに照射前の形状に戻り， ミ セル構造が迅速に回復することが分かった。これより， 紫外光の ON-OFF にともない 3TEG-LPD は長半径の方 向に伸長・伸縮することが明らかとなった。

ミセル構造の時間変化を追跡するために，紫外光照射 2 分間 /暗所静置 4 分間のサイクルを複数回繰り返し た。SANS プロファイルの強度変化を分かりやすく評価 するため, $q$ 值が $0.01 \sim 0.05 \AA^{-1}$ の範囲について 60 秒 間隔で散乱強度の積分值を時間に対してプロットした
(Fig. 6b)。その結果，紫外光照射 ON-OFF にともなう ミセル構造の伸長・収縮のプロセスは, ともに 60 秒以 内に完了することが分かった ${ }^{27)}$ 。

さらに，紫外可視吸収スペクトルの同時測定を行っ た。紫外光照射にともないロフィルラジカルに由来する $580 \mathrm{~nm}$ の吸収ピークが増大した（Fig. 6c）。光照射 ONOFF にともなう $580 \mathrm{~nm}$ の吸光度変化は, SANS の積分 值変化の夕イミングとほぼ一致した。これより, ロフィ ルラジカルの光異性化反応とミセル構造変化はほほタイ ムラグなく進行することが明らかとなった。以上より， 3TEG-LPD が形成するミセルは，紫外光照射にともな い高速で可逆的に構造変化することを見出した。

\section{6 両親媒性ロフィンダイマーが形成するミセルを用い た高速放出制御}

高速光応答する 3TEG-LPD ミセルを用いた被可溶化 物質の放出制御を検討した。モデル薬物として，蛍光を 示すカルセインを 3TEG-LPD のミセル水溶液中に可溶 化させた。蛍光スペクトル測定の結果, $545 \mathrm{~nm}$ にカル セイン由来のピークが観測され，さらに紫外光照射にと もないピークの長波長シフトと蛍光強度の低下が観測さ れた（Fig. 7a）。これより，光照射にともないカルセイ ンがミセル中から放出され，凝集・析出することが分かっ た。

蛍光のピーク強度を時間に対してプロットした結果, 
(a)

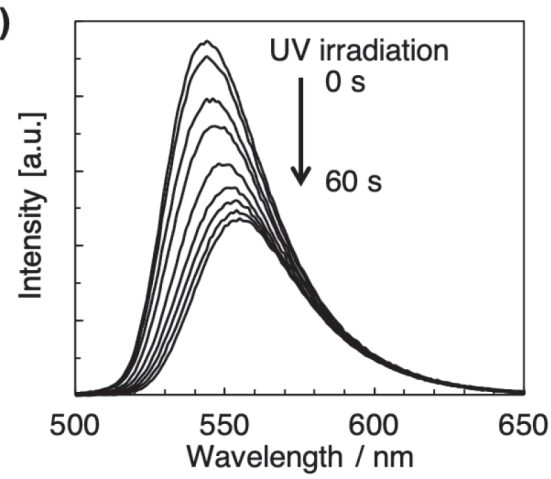

(b)

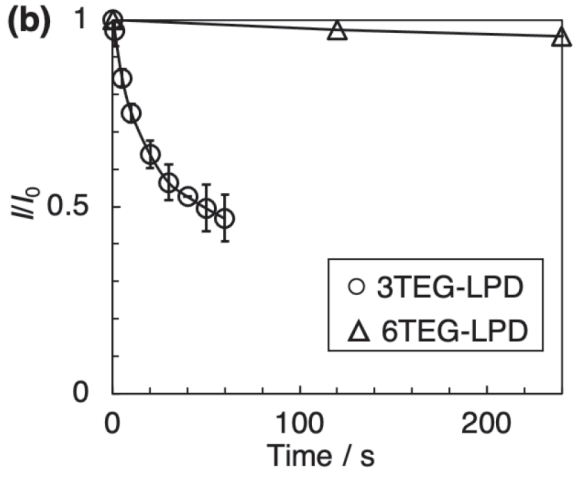

Fig. 7 (a) Variations in fluorescence spectra of $1.0 \mathrm{mM}$ calcein/5.0 mM 3TEG-LPD aqueous solution under UV irradiation. (b) The normalized transient changes in fluorescence intensity at the peaks for $1.0 \mathrm{mM}$ calcein/5.0 mM 3TEG-LPD and 6TEG-LPD aqueous solutions during UV irradiation.

紫外光照射にともなう蛍光変化は 60 秒以内に完了する ことが分かった（Fig. 7b）。これより，紫外光照射にと もなうミセル構造変化が定常状態に至る前に, カルセイ ンが放出されるために十分な可溶化能変化が生じること が分かった。また，光照射にともなうミセル構造変化が 起こらないことを確認している，ミセル構造変化が起こ らない, TEG 基を 12 個持つ両親媒性ロフィンダイマー （6TEG-LPD）を用い，同様にカルセインの放出実験を 行った。結果として, 蛍光変化は観測されず, ミセル中 に可溶化されたミセルが水中に放出されないことが分 かった。これより，3TEG-LPD ミセル系の蛍光変化は, 光照射にともなうミセル構造変化により誘導されること が確認できた。

以上より, 両親媒性ロフィンダイマー（3TEG-LPD） ミセルを用いることで, 可溶化したモデル薬物の高速な 光放出制御を達成できた。

\section{7 おわりに}

本稿では, 光に刺激に応答する界面活性剤の開発とそ の機能評価について紹介した。アゾベンゼン修飾界面活 性剂は, その trans-cis 光異性化にともないミセル形成 能が可逆的に変化した。この可逆的なミセル構造変化を 利用し，光照射によるモデル香料の可溶化放出制御に成 功した。環境への残存性に配慮した桂皮酸修飾光開裂性 界面活性剂を合成し, 界面物性・溶液粘性・微粒子分散 性の光制御に成功した。さらに, 光照射にともなうオン デマンドな機能制御を目指し, 光異性化反応や界面物性・ 分子集合体構造変化の高速化を目的とし, ロフィンダイ マー修飾界面活性剂を合成した。ミセルを形成している ロフィンダイマー修飾界面活性剂から光照射にともない 生成されるロフィルラジカルの再結合反応は, モノマー 溶解している有機溶媒中と比較して, 顕著に高速化する ことが分かった。これは, 分子集合体内部でラジカル種
の拡散が抑制され，再結合反応が起こり易くなったため だと考えられる。さらに, この両親媒性ロフィンダイマー 水溶液の表面張力は, 紫外光の ON-OFF にともない, 秒オーダーで速やかに変化することを明らかにした。さ らに, ミセル構造やその溶液の可溶化能を高速で光制御 することに成功した。特に, この高速なミセル構造変化 は，新たに構築したin situ 小角中性子散乱（SANS）シ ステムを用いることで明らかとなった。これにより, 薬 物や有効成分のオンデマンドな放出制御が可能となる。

最後に, この光応答性分子集合体系を紐解くと,「光 照射 $\rfloor \rightarrow\lceil$ 光異性化 $\rfloor \rightarrow\lceil$ 分子集合体の構造変化 $\rfloor \rightarrow\lceil$ 物性変 化（例：可溶化能)」の大きく分けると 4 つステップを 経てこの系が進行することが分かる。今後は, 各ステッ プの緩和時間やステップ間のタイムラグをより詳細に解 析し, リレー的に進行するそのダイナミクスを理解した い。これは生体内に存在する巨大分子システム・超分子 システムが持つ刺激応答機能の本質的な理解につながる と期待できる。

\section{8 謝辞}

本稿で紹介した研究を遂行するにあたり，多大なるご 指導とサポートを賜りました東京理科大学の土屋好司博 士, 小林一貴さん, 鈴木大輝さんにこの場を借りて感謝 を申し上げます。また，小角中性子散乱（SANS）の実 験でご協力頂きました, 一般財団法人総合科学研究機構 （CROSS）の岩瀬裕希博士, 坂口佳史博士に感謝申し上 げます。

ここで紹介した研究成果の一部は科学研究費補助金・ 若手研究（B）（課題番号：20K15248）からの補助によ り行ったものである。また, 小角中性子散乱 (SANS) の実験は日本原子力研究開発機構 (J-PARC) の物質 · 生命科学実験施設 (MLF) にて実施された（課題番号： 2019C0007)。ここに深く感謝申し上げる。 


\section{文 献}

1) Brown, P.; Butts, C.P.; Eastoe, J. Soft Matter 9, 23652374 (2013).

2) Eastoe, J.; Vesperinas, A. Soft Matter 1, 338-347 (2005).

3) Grommet, A.B.; Lee, L.M.; Klajn, R. Acc. Chem. Res. 53, 2600-2610 (2020).

4) Chen, S.; Costil, R.; Leung, F.K.-C.; Feringa, B.L. Angew. Chemie Int. Ed. 60, 2-26 (2020).

5) Shinkai, S.; Matsuo, K.; Harada, A.; Manabe, O. J. Chem. Soc., Perkin Trans. 2 1261-1265 (1982).

6) Shang, T.; Smith, K.A.; Hatton, T.A. Langmuir 19, 10764-10773 (2003)

7) Shi, H.; Wang, Y.; Fang, B.; Talmon, X.Y.; Ge, W.; Raghavan, S.R.; Zakin, J.L. Langmuir 27, 5806-5813 (2011).

8) Shi, H.; Ge, W.; Oh, H.; Pattison, S.M.; Huggins, J.T.; Talmon, Y.; Hart, D.J.; Raghavan, S.R.; Zakin, J.L. Langmuir 29, 102-109 (2013).

9) Orihara, Y.; Matsumura, A.; Saito, Y.; Ogawa, N.; Saji, T.; Yamaguchi, A.; Sakai, H.; Abe, M. Langmuir 17, 60726076 (2001).

10) Akamatsu, M.; Fitzgerald, P.A.; Shiina, M.; Misono, T.; Tsuchiya, K.; Sakai, K.; Abe, M.; Warr, G.G.; Sakai, H. J. Phys. Chem. B 119, 5904-5910 (2015).

11) Sakai, H.; Orihara, Y.; Kodashima, H.; Matsumura, A.; Ohkubo, T.; Tsuchiya, K.; Abe, M. J. Am. Chem. Soc. 127, 13454-13455 (2005).

12) Matsumura, A.; Tsuchiya, K.; Torigoe, K.; Sakai, K.; Sakai, H.; Abe, M. Langmuir 27, 1610-1617 (2011).

13) Sakai, H.; Aikawa, S.; Matsuda, W.; Ohmori, T.; Fukukita, Y.; Tezuka, Y. J. Colloid Interface Sci. 376, 160-164 (2012).

14) Aikawa, S.; Shrestha, R.; Ohmori, T.; Fukukita, Y.; Te- zuka, Y.; Endo, T.; Torigoe, K.; Tsuchiya, K.; Sakamoto, K.; Sakai, K.; Abe, M.; Sakai, H. Langmuir 29, 56685676 (2013).

15) Akamatsu, M.; Nagai, T.; Fukuda, K.; Tsuchiya, K.; Sakai, K.; Abe, M.; Sakai, H. Colloids Surf. A-Physicochem. Eng. Asp. 564, 108-114 (2019).

16) Fujita, K.; Hatano, S.; Kato, D.; Abe, J. Org. Lett. 10, 3105-3108 (2008).

17) Akamatsu, M.; Suzuki, T.; Tsuchiya, K.; Masaki, H.; Sakai, K.; Sakai, H. Chem. Lett. 47, 113-115 (2018).

18) Akamatsu, M.; Kobayashi, K.; Sakai, K.; Sakai, H. Chem. Commun. 55, 9769-9772 (2019).

19) Akamatsu, M.; Suzuki, T.; Kobayashi, K.; Tsuchiya, K.; Sakai, K.; Sakai, H. J. Oleo Sci. 68, 659-664 (2019).

20) Lund, R.; Brun, G.; Chevallier, E.; Narayanan, T.; Tribet, C. Langmuir 32, 2539-2548 (2016).

21) Kelly, E.A.; Houston, J.E.; Evans, R.C. Soft Matter 15, 1253-1259 (2018).

22) Jia, S.; Graham, B.; Capuano, B.; Tan, A.; Hawley, A.; Boyd, B.J. J. Colloid Interface Sci. 579, 379-390 (2020).

23) Tabor, R.F.; Pottage, M.J.; Garvey, C.J.; Wilkinson, B.L. Chem. Commun. 51, 5509-5512 (2015).

24) Sakaguchi, Y.; Kasai, S.; Oh-uchi, K.; Morikawa, T.; Iwase, H.; Akamatsu, M.; Sakai, H.; Simon, A.-A.A.; Mitkova, M.; Takahashi, R. JPS Conf. Proc. 33, 1-7 (2020).

25) Lund, R.; Willner, L.; Richter, D.; Lindner, P.; Narayanan, T. ACS Macro Lett. 2, 1082-1087 (2013).

26) Jensen, G.V.; Lund, R.; Gummel, J.; Narayanan, T.; Pedersen, J.S. Angew. Chemie-Int. Ed. 53, 11524-11528 (2014).

27) Akamatsu, M.; Kobayashi, K.; Iwase, H.; Sakaguchi, Y.; Tanaka, R.; Sakai, K.; Sakai, H. Sci. Rep. in press. 